поездов и их экономическое значение / Д.А. Мачерет // Железнодорожный транспорт. - 2014. - № 6. - С. 52-55.

12. Кулаєв Ю.Ф. Економіка залізничного транспорту: Навчальний посібник / Ю.Ф. Кулаєв - 2-е вид., переробл. і доповн. - К.: Фенікс, 2012. $240 \mathrm{c}$.

DOI 10.18664/338.47:338.45.v\%vi\%i.133984
13. Пасічник B.I. Управління економікою експлуатаційної роботи залізниць України: навч. посібник для вузів / В.І. Пасічник. - К.: Основа, 2005. - 372 с.

14. Макаренко М.В. Основи управління економічними процесами на залізничному транспорті України. Монографія. - К.: КУЕТТ, 2003. - 478 с.: іл.: Бібліограф. 10 с.

УДК 331.108.02:656.2

\title{
ВПЛИВ УПРАВЛІННЯ ПЕРСОНАЛОМ НА СТРАТЕГІЧНИЙ РОЗВИТОК ЗАЛІЗНИЧНОГО ТРАНСПОРТУ В СУЧАСНИХ УMOBAX
}

Каличева Н.С., к.е.н., доцент, Зленко О.В., магістр (УкрДУЗТ)

Стаття присвячена питанням удосконалення управління персоналу на підприємствах залізничного транспорту. Визначено, щзо управління персоналом галузі повинне здійснюватися в межах стратегічного плану розвитку залізничного транспорту. Розкрито специцбіку управління персоналом із врахуванням соиіальної складової розвитку вітчизняного транспортного сектору. Визначена роль держави при формуванні кадрів на залізничному транспорті, особливо вищої та середньої управлінських ланок.

Ключові слова: кадри, трудові ресурси, залізничний транспорт, удосконалення, управління, стратегічний розвиток, соціальна відповідальність, конкурентоспроможність

\section{ВЛИЯНИЕ УПРАВЛЕНИЕ ПЕРСОНАЛОМ НА СТРАТЕГИЧЕСКОЕ РАЗВИТИЕ ЖЕЛЕЗНОДОРОЖНОГО ТРАНСПОРТА В СОВРЕМЕННЫХ УСЛОВИЯХ}

\author{
Каличева Н.Е., к.э.н, доцент, \\ Зленко Е.В., магистр (УкрГУЖТ)
}

Статья посвящена вопросам совершенствования управления персонала на предприятиях железнодорожного транспорта. Определено, что управление персоналом отрасли долюно осуществляться в рамках стратегического плана развития железнодорожного транспорта. Раскрыта специфика управления персоналом с учетом соичиальной составляющей развития отечественного транспортного сектора. Определена роль государства при формировании кадров на железнодорожном транспорте, особенно высшего и среднего управленческих звеньев.

(C) Каличева Н.Є.,

Вісник економіки транспорту і промисловості № 62, 2018

Зленко О.В. 
Ключевые слова: кадры, трудовые ресурсы, жселезнодорожный транспорт, совериенствование, управление, стратегическое развитие, социальная ответственность, конкурентоспособность.

\title{
EFFECT OF PERSONNEL MANAGEMENT ON STRATEGIC DEVELOPMENT OF RAILWAY TRANSPORT IN MODERN CONDITIONS
}

\author{
Kalicheva N.E., candidate of economic sciences, associate professor, \\ Zlenko O.V., master's degree (USU of RT)
}

One of the essential components of effective governance, especially for such a complex industry as railways, is the upgrading of the staff development program that will meet the needs of workers in terms of their professional and cultural development.

It should be noted that in the management of the personnel of the enterprise there should be a permanent relationship with the general strategy of enterprise development, which is quite characteristic of the railway industry, which in recent years conducts reforms in all areas of activity.

In order for rail transport to be quickly converted to a market economy, we need new creative personnel who could make a certain novelty in the management system and change the stereotypes, but in most cases, there are personnel who do not know all the peculiarities of the industry in the field of rail transport. and do not have the appropriate authority among ordinary employees.

One of the factors of effective management of the company's personnel, especially of such a resource-intensive industry as the railway industry, is the continuous improvement of the level of professional knowledge and skills that characterizes the qualifications of the personnel. Another important factor in the effective management of personnel is the study of its social component.

The state should be the guarantor of the efficient development of rail transport and impose appropriate requirements on its head. After all, the formation of a corresponding professional level of a manager requires a lot of time and expenses, which is possible only if the potential applicant knows about prospects of career growth, will see the possibilities of professional development and will know that it can bring real benefits to the industry and the national economy.

Improvement of the personnel management system for the railway industry should be aimed at increasing the level of professionalism and efficiency of workers of all production units and managers of all levels of management. The same personnel management system should be based on such approaches and principles, the application of which will allow the establishment of key and common factors of influence on the management process, identify possible threats and directions for improving management efficiency.

Key words: human resources, labor resources, railway transport, improvement, management, strategic development, social responsibility, competitiveness.

Постановка проблеми та їі зв'язки 3 науковими чи практичними завданнями. Однією із необхідних складових ефективного управління, особливо для такої складної галузі як залізнична, $є$ оновлення програми розвитку персоналу, що сприятиме задоволенню потреб робітників 3 точки зору їх професійного та культурного розвитку. Тим більше, що за умов посилення конкурентної боротьби на ринку важливе значення для розвитку персоналу мають освіта, професійні знання та вміння, практичні навички та досвід, соціально-

Вісник економіки транспорту і промисловості № 62, 2018 
культурний розвиток, інтелектуальний потенціал та можливість застосувати все це для розвитку підприємства згідно із власними здібностями та компетенціями [1].

Аналіз останніх досліджень i публікацій. Вивчення питань щодо підходів управління кадровою складовою залізничного транспорту розкрито у працях Диканя В.Л., Компанієць В.В., Токмакової І.В., Калініченко Л.Л., Остапюка Б.Я. та інших [2-6], де визначено, що необхідні якісні зміни в традиційних підходах щодо управління на підприємствах транспортної сфери та, зокрема, залізничного транспорту. Адже ті підходи, які протягом останніх років використовувалися в галузі не дали дієвого результату в підвищенні конкурентоспроможності вітчизняних підприємств залізничного транспорту на ринку транспортних послуг.

Мета статті. Дослідження ролі управління персоналом на залізничному транспорті в сучасних умовах господарювання та їх вплив на стратегічний розвиток галузі.

Викладення основного матеріалу дослідження. Для такої складної галузі, як залізничний транспорт, управління персоналом має базуватися на таких концепціях [7]:

- виробнича, суттю якої $\epsilon$ дослідження запитів споживачів та врахування потреб ринку відносно соціальної відповідальності підприємства та чесної конкуренції, так як в сучасній ринковій економіці клієнти орієнтуються на лише на ціну та якість товару, а й на імідж та репутацію підприємства;

- фінансово-економічна, базується на всіх економічних показниках управління персоналом;

- соціальна, в основу якої покладені гуманітарні цілі розвитку та задоволення потреб робітників, що $\epsilon$ досить актуальним 3 огляду на соціальний напрям розвитку кадрової політики підприємств та виражається в створенні таких умов праці, що б робітники були задоволені своєю роботою, відчували приналежність до кінцевого результату, прагнули до саморозвитку та вдосконалення, тощо.

Потрібно зазначити, що при управлінні персоналом підприємства має бути постійний взаємозв' язок із загальною стратегією розвитку підприємства (рис. 1), що є досить характерним для залізничної галузі, яка протягом останніх років проводить реформи на всіх напрямах діяльності.

Взагалі, стратегічний розвиток персоналу має носити довготривалий характер, тому що для досягнення необхідних практичних навичок працівник має почати працювати на посаді найнижчого рівня та протягом певного часу, набуваючи досвіду, підійматися кар'єрними сходами. Лише в цьому випадку працівник може бути професіоналом своєї справи та приймати участь в питанням розвитку та управління підприємством.

На даний час залізнична галузь, перебуваючи в стані реструктуризації, має проблеми, пов'язані із становленням нових принципів корпоративної культури [8]. Причиною такого стану $є$ зміна поколінь працівників та зміна орієнтирів розвитку всього транспортного сектору країни.

Для того, щоб залізничний транспорт як найшвидше перелаштувався до діяльності в умовах ринкової економіки потрібні нові креативні кадри, які б змогли внести певну новизну в систему управління та змінити стереотипи, але в більшості випадків на залізничний транспорт потрапляють кадри, які не знають всіх особливостей роботи галузі та не мають відповідного авторитету серед рядових працівників. 


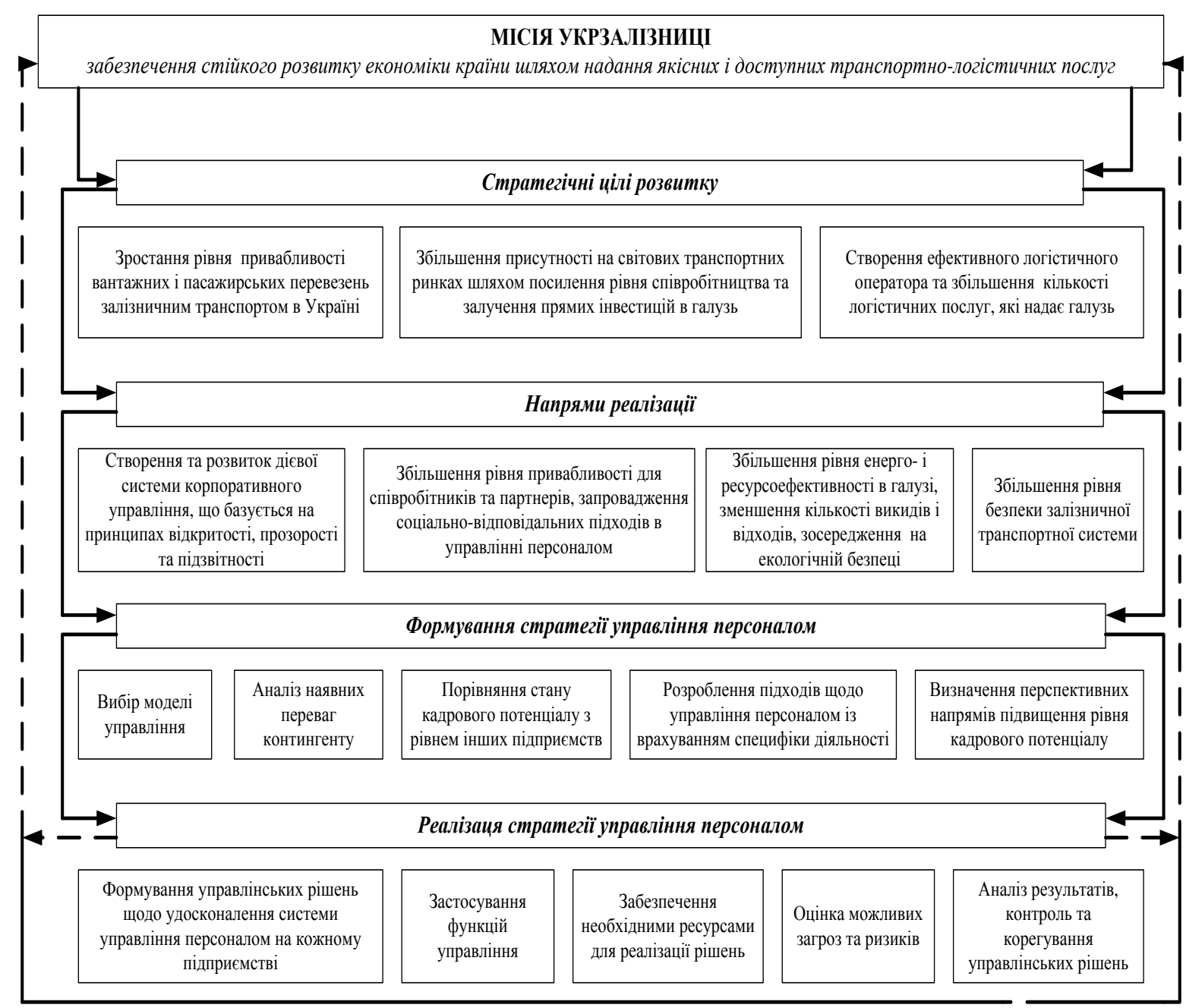

Рис. 1. Схема взаємозалежності загальної стратегї розвитку залізничного транспорту із системою управління персоналом

Одним 3 факторів ефективного управління персоналом підприємства, тим більше такої ресурсо- та трудоємкої галузі, як залізнична, $\epsilon$ постійне підвищення рівня професійних знань та навичок, що характеризує кваліфікацію персоналу.

Відносно рівня кваліфікації виділяють наступні групи робітників [9]:

- висококваліфіковані - мають висковий рівень професійних знань та практичних навичок, їх діяльність спрямована на виконання особливо складних робіт;

- кваліфіковані - мають значний досвід роботи та приймають участь у організації виробничо-господарського процесу на підприємстві;

- малокваліфіковані - займаються виконанням робіт невисокої складності, їм притаманний невеликий досвід роботи у практичній діяльності;

- некваліфіковані - переважно здійснюють діяльність пов'язану із обслуговуванням виробничогосподарського процесу та виконують роботу, котра вимагає мінімального рівня спеціальної підготовки.

Підприємство, яке прагне бути конкурентоспроможним на ринку, має прагнути до постійного підвищення рівня кваліфікації персоналу, що для підприємств залізничного транспорту виражається в зацікавленні керівництва щодо постійного зростання рівня теоретичної та практичної підготовки кадрів. Адже, наявність кваліфікованого персоналу позначиться на поточному стані та перспективних напрямах розвитку підприємства, що $€$ важливим для 
залізничного транспорту [10], за рахунок збільшення професійно-практичного, інтелектуального та інформаційного рівня працівників. Це досягається на підприємстві за рахунок оновлення чи вдосконалення системи професійної освіти, створення умов для самореалізації та самовираження й розкриття творчого та наукового потенціалу робітників. Коли робітники отримують можливість підвищити рівень знань, здійснити творчі задуми, отримати нові практичні навички та використати їх 3 користю для підприємства, то вони зможуть сприяти його ефективному розвитку за рахунок швидкої адаптації до викликів зовнішнього середовища, пришвидшення рівня запровадження інновацій, креативного та гнучкого мислення, тощо.

Ще одним важливим фактором ефективного управління персоналом $\epsilon$ дослідження його соціальної складової, що досить грунтовно розкрито в роботах [4-5; 11-12]. Зокрема Компанієць В.В. зазначає, що для ефективного розвитку залізничного транспорту, коли галузь прагне стати частиною європейської транспортної системи, потрібно вдосконалювати не лише його технікотехнологічну складову шляхом оновлення інфраструктури для надання якісних та безпечних послуг 3 перевезення, а й вдосконалювати управлінські стандарти 3 точки зору етики та культури бізнесу, корпоративної соціальної відповідальності. Це забезпечить підвищення рівня управління та сприятиме створенню нової моделі управління із врахуванням людського та соціального аспектів діяльності підприємства.

Для такої складної в технічному та організаційному планах галузі, як залізничний транспорт, котра має виконати досить багато перетворень для досягнення поставлених стратегічних завдань, велике значення має створення дієвого управлінського центру iз кваліфікованим персоналом.

$$
\text { У роботах Компанієць В.В., }
$$

Польової В.В., Остапюка Б.Я., Калініченко Л.Л. наголошується на необхідності «виховувати» власних керівників вищої ланки для залізничного транспорту [5-6; 11-12] шляхом створення відповідних навчальних закладів та структур, що сприятиме оцінці сильних та слабких сторін керівників всіх рівні та дозволить їх посилити за рахунок постійного вдосконалення та оновлення навчальних програм відповідно до сучасних ринкових потреб.

Держава має бути гарантом ефективного розвитку залізничного транспорту та висувати відповідні вимоги до його керівника. Адже на формування відповідного професійного рівня керівника потрібно багато часу та витрат, що можливе лише за умови, коли потенційний претендент знатиме про перспективи кар'єрного росту, бачитиме можливості професійного розвитку та знатиме, що зможе принести реальну користь галузі та національній економіці.

Ще одним важливим фактором ефективного управління персоналом підприємства $є$ створення сприятливого морально-психологічного клімату в колективі за рахунок психологічної сумісності робітників, що досягається шляхом оцінки особистісної поведінки працівників, їх розумових можливостей, психічного стану, тощо [13].

Тож, удосконалення системи управління персоналом залізничної галузі має складатися 3 наступних етапів:

- планування потреби в людських pecypcax, визначення їх кількісного та якісного складу;

- формування професійних та практичних вимог до кандидатів;

- визначення підходів до вибору кадрів (опитування, анкетування, тестування, співбесіда, інтерв'ю, тощо); - перевірка професійних здібностей (випробувальний етап);

- прийняття на посаду за умови постійного підвищення професійного та практичного рівні знань (підвищення кваліфікації, стажування, перепідготовка, 
тощо).

Застосування цих етапів не $\epsilon$ «новинкою» для більшості підприємств, але комплексний підхід до відбору кадрів для залізничного транспорту сприятиме постійному зростанню їх якості, що, в майбутньому, сприятиме ефективному розвитку галузі. Тим більше, що в нашій країні розстановка керівних кадрів вищої управлінської ланки відбувається в більшості випадків за зовсім іншими принципами, в результаті чого керівниками стратегічних галузей та відомств стають фахівці із загальним уявленням про особливості їх діяльності.

Таким чином, удосконалення системи управління персоналом для залізничної галузі має бути орієнтована на підвищення рівня професіоналізму та результативності працівників всіх виробничих підрозділів та керівників всіх рівнів управління. То ж система управління кадрами повинна грунтуватися на таких підходах i принципах, застосування яких дозволить встановлювати ключові та пересічні чинники впливу на управлінський процес, виявляти можливі загрози та напрями підвищення ефективності управління (рис.2).

Тим більше, що правильне формування системи компетентностей трудових ресурсів підприємства сприятиме його розвитку в межах стратегічних планів розвитку, забезпечить соціально-культурне зростання, сприятиме оцінці якості кадрового потенціалу підприємства та дозволить оптимізувати кадровий склад всіх структурних підрозділів залізничного транспорту [14].

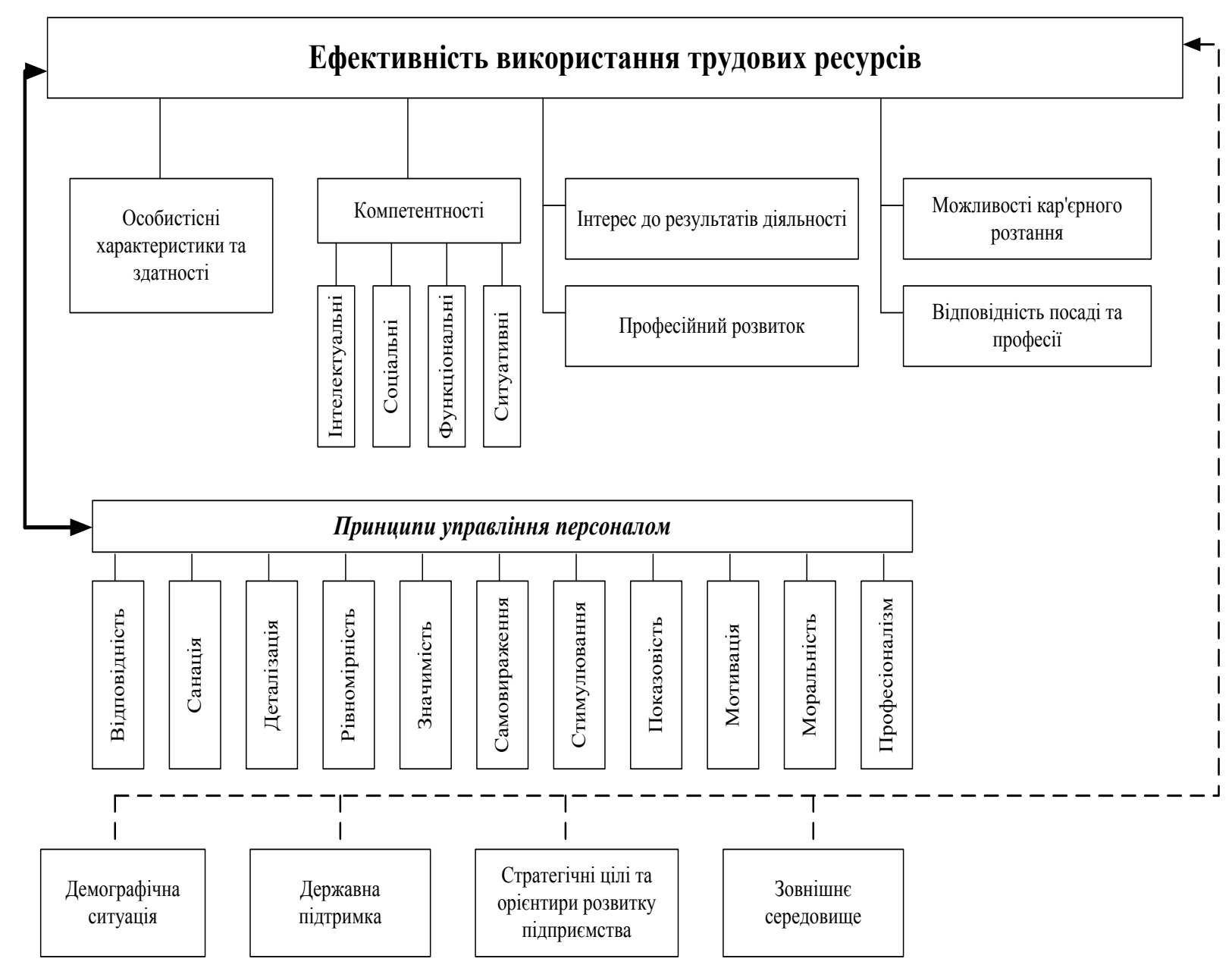

Рис. 2. Функиіонально-структурна схема управління персоналом на залізничному транспорті 
Також, потрібно зазначити, що підвищення ефективності застосування трудових ресурсів неможливе без вирішення питань щодо впровадження нових принципів та підходів в управлінні, що сприяє максимізації компетенцій персоналу підприємства i, як наслідок, нарощенню якісного складу трудових ресурсів. I значну роль в цьому має відігравати держава, як регулятор якості життя, за рахунок регулювання рівня зайнятості населення, надання можливостей для професійного росту та культурного розвитку; регулювання рівня охорони здоров'я та безпеки життєдіяльності; соціального захисту; екологічної безпеки; захисту громадських прав та обов'язків; визначення гідного рівня оплати праці; регулювання доходів; проведення гендерної політики; гарантування безпеки та інших чинників.

Висновки. Таким чином, ефективний розвиток залізничної галузі залежить від кадрової складової, яка $€$ однією 3 рушійних сил його функціонування.

Тож, застосування нових більш сучасних підходів в управлінні персоналом сприятиме практичному вирішенню питань щодо удосконалення системи управління персоналом на залізничному транспорті, грунтуючись на базі комплексної системи реалізації та визначення ефективності запровадження підходів стратегічного управління, приймаючи до уваги стратегічні завдання розвитку галузі.

\section{СПИСОК ВИКОРИСТАНИХ ДЖЕРЕЛ}

\section{1. Фатхутдинов,}

P.A. Конкурентоспособность организации в условиях кризиса: экономика, маркетинг, менеджмент. / Р.А. Фатхутдинов М.: Издво книготорг. центр «Маркетинг», 2005. $892 \mathrm{c}$.

2. Дикань В.Л. Економіка праці на підприємствах залізничного транспорту: підручник / В.Л. Дикань, Ю.В. Єлагін, Т.Г. Сухорукова. - Х.: УкрДАЗТ, 2012. - 275 с.
3. Компанієць В.В. Стратегія людського розвитку та зміни у підготовці кадрів залізничного транспорту / B.В. Компанієць// Вісник економіки транспорту і промисловості.-Харків, УкрдАЗТ, 2010. № 31 204-212 с.

4. Токмакова I.В. Мотивація трудової поведінки працівників залізничного транспорту в умовах реформування / I.B. Токмакова // Вісник економіки транспорту та промисловості. - 2013. - №44. - С. 286-289.

5. Калініченко Л.Л. Методологічний підхід до управління персоналом підприємств залізничного транспорту в умовах реформування галузі: монографія / Л.Л. Калініченко. - Х.: УкрДАЗТ, 2012. - 420 с.

6. Остапюк Б. Я. Концепція залучення персоналу ПАТ «Українська залізниця» до управління та ефективної реалізації його корпоративних задач / Б. Я. Остапюк // Фінансова інфраструктура: формування, проблеми та перспективи розвитку в умовах інноваційної економіки : матеріали Міжнар. наук.-практ. конфер. (Київ, 7-8 листопада 2014 р.). - К. : ГО «Київський економічний науковий центр», 2014. Ч1. - C. $115-116$.

7. Захарчин Г.М. Корпоративна культура/ Г.М. Захарчин, Н.П. Любомудрова, Р.О. Винничук, Н.В. Смолінська / За ред. Г.М. Захарчин. Львів, 2011. - 317 с.

8. Каличева Н.С. Методологічні аспекти підвищення конкурентоспроможності підприємств залізничного транспорту за рахунок управління конкурентними позиціями/ Н.Є. Каличева// Науковий вісник

Херсонського державного університету. Серія: Економічні науки. - Херсон, 2017. Вип. 27. - Ч. 1. - С. 139 - 142.

9. Отенко И.П. Механизм управления потенциалом предприятия: науч. изд. / И.П. Отенко, Л.М. Малярец. Х.: ХГЭУ, 2003. -220 c.

10.Основні аспекти стратегії розвитку ПАТ «Укрзалізниця» [Електронний ресурс]. - Режим доступу: 
http://www.uz.gov.ua

Presentation_fin1.pdf

11. Компанієць В.В. Управління розвитком соціально-економічних систем у духовно-моральному та соціокультурному вимірі. - Частина II. Якість управляння соціальноекономічними системами: духовноморальні та культурні пріоритети (на прикладі залізничного транспорту): монографія / В.В. Компанієць. - Харків: УкрДАЗТ, 2012. - 296 с.

12. Польова В.В. Оцінка ефективності трудової мотивації працівників залізничного транспорту/ В.В. Польова// Зб. наук. праць ДЕТУТ. Серія

DOI 10.18664/338.47:338.45.v\%vi\%i.133993
«Економіка і управління».- К.: ДЕТУТ, 2014.- Вип. 27.- С. 134-145.

13. Каличева Н.Є. Удосконалення системи управління персоналом в умовах розвитку підприємства / Н.Є. Каличева, M.I. Стецюк// Вісник економіки транспорту i промисловості: збірник науково-практичних статей. - Харків: УкрДАЗТ, 2015. - Вип. 49. - С. 195 - 198.

14. Назаренко І.Л. Оцінка та оптимізація кадрового потенціалу дирекції залізничного транспорту/ І.Л. Назаренко// Вісник економіки транспорту та промисловості: збірник науковопрактичних статей. - Х.: УкрДАЗТ, 2013. № 44. - С. 70-74.

\title{
УДК 625.144.5
}

\section{ОПТИМИЗАЦИЯ ЗАТРАТ НА РЕКОНСТРУКЦИЮ ЖЕЛЕЗНОДОРОЖНОЙ ЛИНИИ ПОД СКОРОСТНОЕ ДВИЖЕНИЕ}

\author{
Кравченя И.Н., к.т.н., доцент, \\ Дубровская Т.А., ст. преподаватель (БелГУТ)
}

Повышение скоростей движения поездов на сущзествующих железнодорожных линиях - одно из приоритетных направлений на железнодорожном транспорте.

Рассмотрена задача определения оптимальных скоростей движения поездов каждой категории в кривых при оптимальном возвышении наружного рельса, увеличении значения непогашенного ускорения, соблюдении условия равнонагруженности рельсовых нитей, условия комфортабельности езды пассажиров, при которых приведенные расходы на увеличение скорости в кривых будут минимальными.

Ключевые слова: жселезнодорожный транспорт, скоростное движение, ускорение, возвышение рельса, круговые кривые, метод неопределенных множителей Лагранжа.

\section{ОПТИМІЗАЦІЯ ВИТРАТ НА РЕКОНСТРУКЦІЮ ЗАЛІЗНИЧНОЇ ЛІНІЇ ПІД ШВИДКІСНЕ РУХ}

\author{
Кравченя І.Н., к.т.н., доцент, \\ Дубровская Т.А., ст. викладач (БелГУТ)
}

Підвищення швидкостей руху потягів на існуючих залізничних линиях - одно з пріоритетних напрямів на залізничному транспорті. Швидкісні перевезення 